\title{
16. Environmental Conservation and Indigenous Development through Indigenous Protected Areas and Payments for Environmental Services: A review
}

\author{
Nanni Concu
}

\section{Introduction}

Payments for Environmental Services (PES) are instruments to promote conservation goals and development in rural and poor communities (Pagiola et al. 2008. The use of PES in Indigenous Australia has only recently emerged as a potential alternative to government funding. PES schemes are strongly linked to Indigenous natural resource management (NRM) carried out by traditional owners and custodians (hereinafter TOs) and Indigenous land and sea management groups, and increasingly formalised through Indigenous Protected Areas (IPAs).

Both PES and IPAs are hailed as alternatives to other forms of economic participation in the Australian economy. The Indigenous development discourse in Australia nowadays strongly emphasises participation in the mainstream economy as the fundamental element in overcoming the socioeconomic disadvantages of Indigenous communities (COAG 2009). Under this paradigm, economic participation is equated with entrepreneurship and employment, and government policies and public/private cooperation aim to provide job opportunities for Indigenous Australians in manufacturing, mining, agriculture, forestry, retail and other services (AEC 2010; COAG 2009). Reforms of the Community Development Employment Projects (CDEP) program, for instance, are meant to push Indigenous people into this sort of 'real' employment (Hudson 2009).

This model of economic participation might suit some Indigenous Australians. Others, particularly in remote areas, ${ }^{1}$ might face different economic conditions that make employment in the mainstream economy a different challenge: in remote areas job opportunities are limited and economic participation would

\footnotetext{
1 For a definition of remote and very remote areas, see ABS (2007). Remoteness is measured by physical distance by road to the nearest urban centre. According to the Australian Bureau of Statistics, about 26 per cent of the Aboriginal and Torres Strait Islander population lives in remote and very remote regions (ABS 2010).
} 
require relocation or increased mobility, potentially resulting in further economic disadvantage (Biddle 2009); job creation for Indigenous people in remote communities has also had limited success in and around mining leases (Altman and Martin 2009); the low agricultural potential in large parts of the Indigenous estate does not allow for investment in this sector (Luckert et al. 2007); furthermore, Indigenous Australians might also have different sets of incentives and cultural demands precluding direct transfer of non-Indigenous models of entrepreneurship and employment (Austin-Broos 2003; Lindsay 2005).

An alternative form of Indigenous economic participation is based on commercialisation of environmental goods and services through PES and government-supported NRM activities. This mix of market-based instruments and government funding is at the core of proposals for establishing Indigenous NRM-based economies (Altman and Whitehead 2003; Hill et al. 2007; Luckert et al. 2007; Woinarski et al. 2007). By trading environmental goods and services through market exchanges and public funding for NRM activities, Indigenous communities could access financial resources for the creation of culturally appropriate NRM employment and livelihoods.

Contrasted with other forms of employment, Indigenous NRM promotes the integration of economic growth with conservation goals in line with Indigenous aspirations to live on and care for their country (NLC 2006). By engaging Indigenous ecological knowledge and social capital, Indigenous NRM gives Indigenous landowners the possibility to match work obligations with cultural priorities, kin responsibilities and conservation goals (NLC 2006; Russel-Smith et al. 2009). Indigenous landowners in remote areas are also geographically well placed to address the complexities of many environmental issues in remote regions of the Australian continent (Luckert et al. 2007). Further, the Indigenous estate - covering about 20 per cent of the Australian landmasshas internationally significant environmental and cultural values (Altman et al. 2007). These factors - ecological knowledge, cultural and social capital, ownership of important environmental assets, location and low productive potential of the Indigenous estates - give Indigenous landowners a comparative advantage (if not an absolute advantage) in the provision of environmental services.

Examples of environmental services include fire management for carbon abatement, biodiversity conservation, and feral animal and invasive species control. These NRM activities have important indirect effects on other economic sectors such as tourism, commercial and recreational fishing, and agriculture. The Indigenous art market also benefits from Indigenous NRM, as it is dependent on the conservation of local environments and Indigenous NRM activities for the provision of natural products such as fibres, bark, timber and dyes for art production (see MAC 2008). Hence, Indigenous NRM generates environmental 
outcomes for the benefits of the Australian and international communities by creating bundles of private and public goods. Both government funding and PES are instruments to internalise - that is, turn them into private gains - the public benefits associated with Indigenous NRM, and to promote the private provision of environmental goods.

Indigenous NRM has become increasingly formalised through the establishment of IPAs. At the time of writing, there are 38 IPAs, comprising 23 per cent of Australia's protected areas or 2.8 per cent of the landmass of Australia (DEWHA 2010c). Market-based instruments for land management and environmental conservation are also increasingly being proposed and trialled. Muller (2008) and Greiner et al. (2009) advocate PES as an opportunity for Indigenous landowners to support their environmental and cultural management activities in northern Australia.

Dhimurru Aboriginal Corporation (hereinafter Dhimurru) and Djelk Rangers both have some experience of using PES schemes. They both also manage two important IPAs. I review their experience in order to assess the functioning of PES schemes as instruments to promote Indigenous conservation and development aspirations. This assessment highlights how Indigenous comparative advantage in NRM could be realised, what services Indigenous landowners are selling or providing through PES schemes and/or government support, and identify what is working and what is not. This would in turn inform both Indigenous NRM and potential buyers on best PES practices.

This chapter is organised in five sections, starting with a short introduction to Australia's IPAs. In section two, I discuss the theoretical framework for PES and its application to Indigenous NRM. Section three contains a description of Dhimurru and Djelk IPAs, the types of NRM activities both ranger groups routinely carry out, and estimates of resources allocated to each NRM activity. The review of PES schemes used by Dhimurru and Djelk to fund their NRM activities is in section four, and these schemes are discussed more broadly in section five.

\section{Australia's Indigenous Protected Areas}

The Indigenous Protected Area (IPA) program is the first national NRM program to specifically target Indigenous landowners. The IPA program was established in 1996 as part of the Federal Government's commitment to expand the National Reserve System (NRS), and thus meet Australia's obligations under Article Eight of the International Convention on Biodiversity Conservation (Gilligan 2006; Langton et al. 2005). IPAs are based on a voluntary agreement between TOs and the Federal Government through which Indigenous-owned land is assigned 
to the protection of biodiversity and the conservation of cultural resources. As such, IPAs have no legal basis - that is, they are not regulated by any Commonwealth, State or Territory legislation - but are managed as part of the NRS according to international conservation standards (Gilligan 2006). At the time of writing, there are 38 declared IPAs, with consultation projects under way for another forty. IPAs make up 23 per cent of Australia's NRS (DEWHA 2010c). Consultations are also under way to establish sea country IPAs (DEWHA 2010d).

The IPA program is generally reputed as an example of successful collaboration between governments and Indigenous landowners and as one of Australia's most successful conservation arrangements (Gilligan 2006). On the one hand, the Australian community has gained bio-regionally significant land as part of the NRS. The millions of hectares TOs voluntarily contribute to the NRS are acquired with little public expenditure. In its first 10 years (1996-2006), the IPA program received about $\$ 12$ million in funding - equivalent to less than $\$ 1$ per hectare of protected land - while making significant contributions to the NRS in terms of both area and biodiversity value (Gilligan 2006). As some of the land acquired by or returned to TOs had previously been exploited for pastoral or agricultural enterprises, it was often highly degraded. Indigenous landowners have taken it upon themselves to restore and conserve their traditional estates - again, with minimal investment from governments (Gilligan 2006; Langton et al. 2005). For Indigenous landowners, IPAs are an exercise of Indigenous governance. Control of the IPAs ultimately resides with senior traditional owners. IPAs are also a means to achieve a set of social, economic, environmental and cultural benefits (BAC 2009), and provide effective protection of Indigenous values (Dhimurru 2008). Gilligan (2006) reports that the majority of Indigenous communities living within IPAs received economic, educational, social and health benefits from the program.

Other national NRM initiatives have not been as successful. The National Landcare Program, the National Heritage Trust and the National Action Plan for Salinity and Water Quality provided more than $\$ 4.5$ billion of public money to address land degradation (Kingwell et al. 2008). Indigenous participation in these NRM programs and access to funds have been relatively poor (Smyth et al. 2004). They also have not had relevant environmental outcomes, and taxpayers' money has not been used efficiently (Kingwell et al. 2008; Marsh and Pannell 2000). ${ }^{2}$

2 In 2008, the Federal Government scrapped the national programs and set up a new NRM framework: the Caring for Our Country initiative. This initiative integrates the Landcare, National Heritage Trust programs and Indigenous-specific programs such as Indigenous Protected Areas (IPAs) and Working on Country programs (Commonwealth of Australia 2010). 


\section{Payment for Environmental Services}

The limited success of programs such as Landcare in Australia, or similar conservation projects in other countries (Wunder 2005), has spurred the development of instruments such as PES to address the global decline of biodiversity and poverty issues. PES are based on the idea that increasingly scarce environmental services can potentially be traded. Environmental service beneficiaries make direct, contractual and conditional payments to land managers for adopting management practices that secure ecosystem conservation and/or restoration (Wunder 2005). These contractual commitments have the potential to improve the livelihoods of economically disadvantaged communities. In other words, PES create markets where there is a market failure. The logic of PES is illustrated in Figure 16.1.

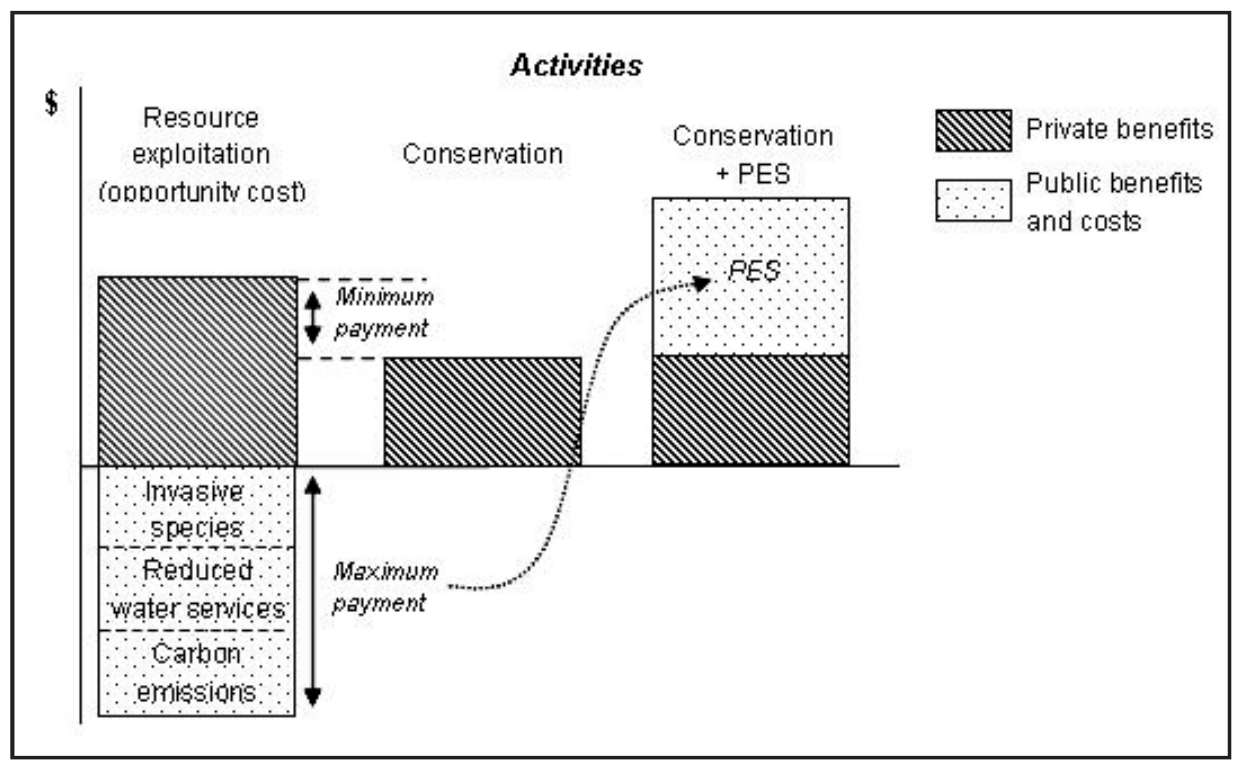

Figure 16.1 The logic of PES

Land managers often receive little financial benefit from conservation practices. When these benefits are less than the benefits from productive use of the land, such as agriculture or forestry, and when such productive activities impose costs on others (the global community, downstream populations, other land managers), PES could make conservation practices more attractive by paying land managers to adopt them.

Engel et al. (2008) list a set of conditions for the successful implementation of PES

- natural ecosystems are mismanaged because many of their benefits are externalities from the point of view of the owners 
Indigenous Participation in Australian Economies II

- buyers can be identified and are willing to pay for environmental services

- sellers of environmental services are also identified

- transactions are voluntary

- environmental services are well defined

- payments are conditional on effective service provision.

The first point describes the case of market failure. Arguably, this does not seem to apply to the Indigenous estate. Indigenous management practices are usually considered sustainable. Hunting and fishing according to Indigenous customs ensure that resources are not exhausted (Dhimurru 2006). Williams, for instance, describes a set of harvesting activities - including fire management, fish trapping and gathering bush products - that is meant to avoid waste, assure regeneration and maximise the productivity of the land (Williams 1986:93-4). The breakdown of pre-colonial Indigenous NRM and European models of agricultural exploitation are indeed some of the causes of environmental degradation on Indigenous lands. Alien species such as mission grass and buffaloes were introduced for commercial and agricultural purposes (Parson and Cuthberson 1992:119-21; Smith 1995:59). Depopulation is also a cause of declining environmental conditions in the Indigenous estate (Altman and Whitehead 2003). It can be argued that depopulation is partly a symptom of increasing opportunity costs for Indigenous people. Residing in remote or very remote areas requires forgoing economic opportunities that urban settings might offer. According to Biddle (2009), however, Indigenous people who move to urban areas do not do as well as those already residing there, and might do worse than those who stayed in remote centres.

All these causes of environmental degradation are direct consequences of policy distortions, rather than market failure. Addressing such distortions is an obvious first solution (Heath and Binswanger 1996). Once policy distortions are removed, it would be possible to adopt PES schemes that give incentives to Indigenous landowners to reside on their estates, improve traditional management practices by incorporating non-Indigenous science, and hence provide environmental services for the whole of Australia. Recent reforms by the Commonwealth and NT Governments of Indigenous policies are, however, further adding to such distortions by cutting support for Indigenous people living remotely (see COAG 2009).

Private and public benefits and costs on Indigenous-owned land are articulated in Figure 16.2. The low productive potential of most of the Indigenous estate implies that the private benefits of resource exploitation are lower than the private benefits owners gain in other parts of the Australian continent. There is a general agreement that Indigenous land managers have low opportunity costs, either because their land has low natural fertility (Greiner et al. 2009) 
or because of past agricultural practices, such as in the case of pastoral leases bought back by Indigenous organisations to set up IPAs (see Table 16.1). Low opportunity costs mean that Indigenous landowners potentially have a comparative advantage in environmental service provision. That is, they can provide environmental services with the highest relative efficiency in terms of the other goods and services that they extract from their land. Low opportunity costs also imply little bargaining power when negotiating PES. In many cases, the private benefits of Indigenous NRM can be assumed to be higher than benefits from other forms of resource use. This reflects the strong connection between Indigenous culture and the natural environment: Indigenous environmental conservation is strongly based on Indigenous cultural beliefs and philosophies (Williams 1986). In these circumstances, Indigenous landowners clearly would not be able to negotiate PES schemes by threatening, say, to exploit resources for agricultural enterprises. For instance, Muller (2008) mentions a Customs representative questioning the need to pay Indigenous rangers for something Customs gets for nothing.

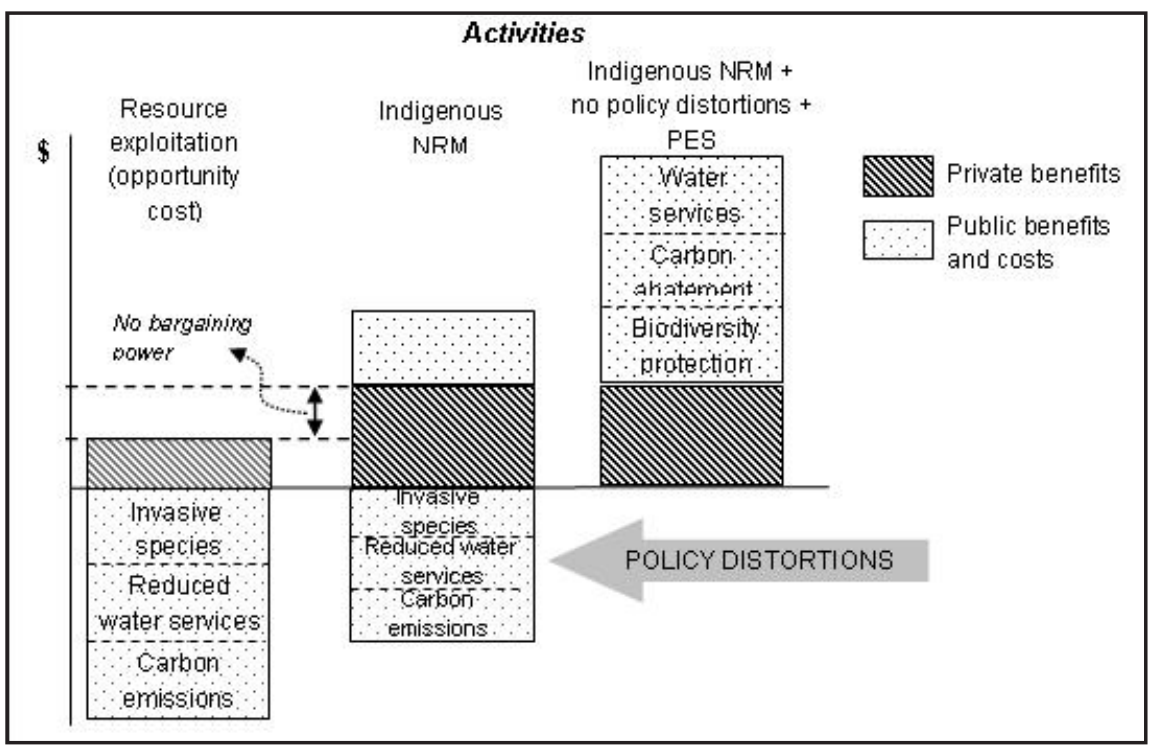

Figure 16.2 Benefits and costs from the Indigenous estate under different management options 
Indigenous Participation in Australian Economies II

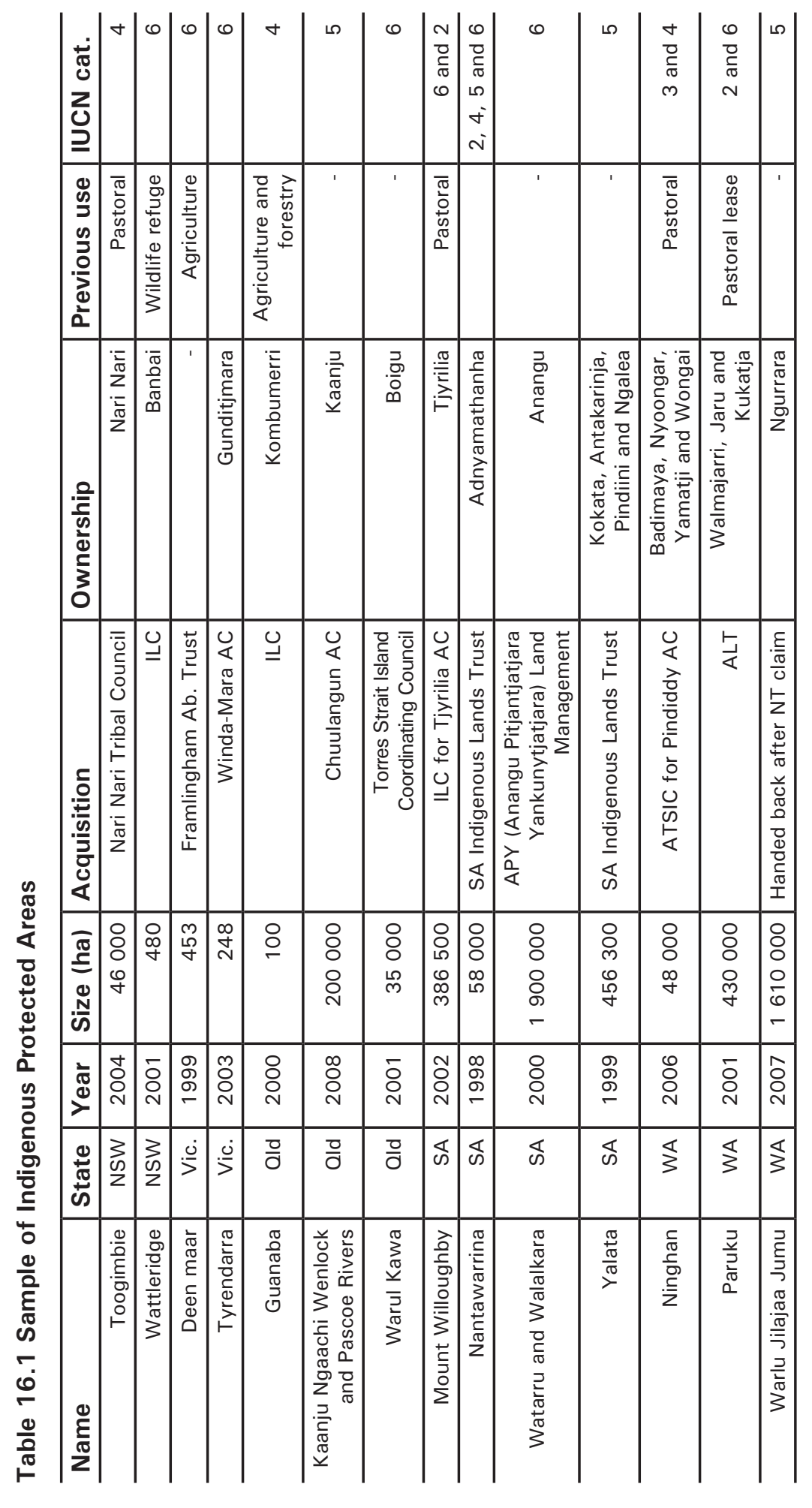


16. Environmental Conservation and Indigenous Development

\begin{tabular}{|c|c|c|c|c|c|c|c|c|c|c|}
\hline 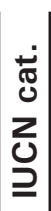 & 0 & مـ & مـ & 0 & 0 & مـا & 0 & 0 & 0 & 0 \\
\hline 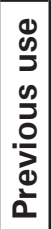 & 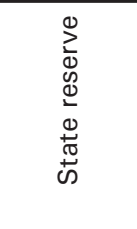 & 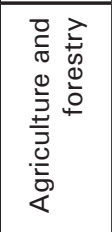 & 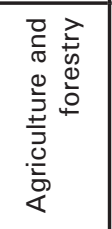 & $\begin{array}{l}\bar{\pi} \\
\overline{0} \\
\frac{0}{0} \\
0 \\
0\end{array}$ & ' & 1 & 1 & 1 & 1 & 1 \\
\hline $\begin{array}{l}\frac{2}{c} \\
\frac{0}{c} \\
\frac{0}{0} \\
\frac{2}{3} \\
0\end{array}$ & I & 1 & ' & 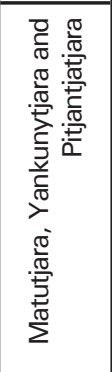 & 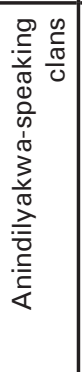 & $\begin{array}{l}\frac{\infty}{2} \\
\frac{0}{0} \\
0 \\
0 \\
\frac{5}{0} \\
\frac{1}{2}\end{array}$ & 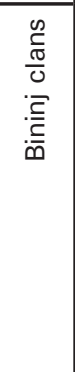 & 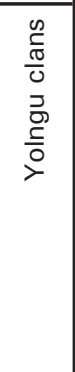 & I & 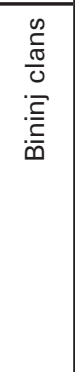 \\
\hline 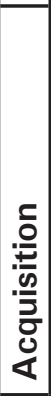 & 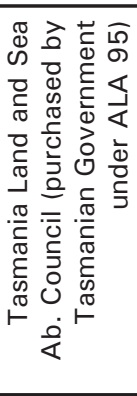 & 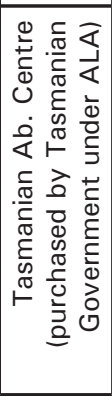 & 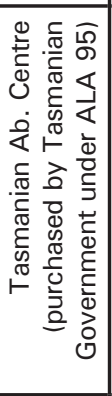 & 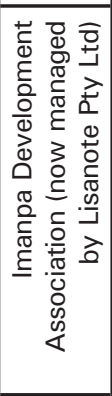 & 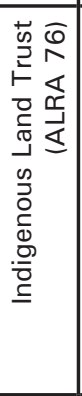 & 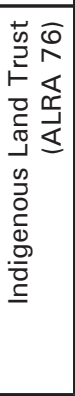 & 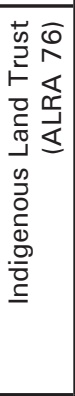 & 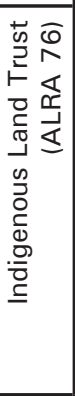 & 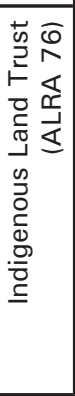 & 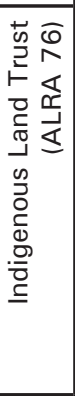 \\
\hline $\begin{array}{l}\widetilde{\pi} \\
\stackrel{0}{=} \\
\stackrel{0}{N} \\
\frac{\tilde{N}}{\omega}\end{array}$ & 음 & 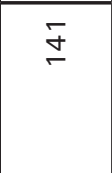 & $\begin{array}{l}\text { ナ } \\
\stackrel{\Omega}{\circ}\end{array}$ & $\begin{array}{l}\circ \\
\varnothing \\
\circ \\
\text { లె }\end{array}$ & $\begin{array}{l}\text { ঃ } \\
\circ \\
\text { ০ }\end{array}$ & $\begin{array}{l}8 \\
8 \\
\text { ஸे }\end{array}$ & 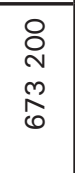 & $\begin{array}{l}\circ \\
\text { ○ } \\
\circ \\
\stackrel{\circ}{0}\end{array}$ & $\begin{array}{l}8 \\
8 \\
\circ \\
\searrow \\
\circ \\
+\end{array}$ & $\begin{array}{l}\overline{5} \\
\circ \\
\text { मे } \\
\text { ले } \\
-\end{array}$ \\
\hline ¿ & $\begin{array}{l}\text { Ф) } \\
\text { Ф) }\end{array}$ & g & ষ & $\begin{array}{l}\text { : } \\
\text { ठे }\end{array}$ & $\begin{array}{l}\text { ஜ } \\
\text { ¿ }\end{array}$ & $\begin{array}{l}\text { ¿ } \\
\text { ¿ }\end{array}$ & $\begin{array}{l}\text { : } \\
\text { ○े }\end{array}$ & $\begin{array}{l}\stackrel{0}{ } \\
\stackrel{\text { Dे }}{ }\end{array}$ & 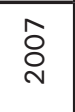 & $\begin{array}{l}\text { 오 } \\
\text { 으 }\end{array}$ \\
\hline 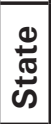 & 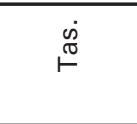 & $\begin{array}{c}\dot{\rho} \\
\stackrel{\sigma}{\sigma}\end{array}$ & $\begin{array}{l}\dot{\oplus} \\
\stackrel{\sigma}{\leftarrow}\end{array}$ & 乞 & 乞 & 々 & 々 & 乞 & 乞 & 乞 \\
\hline$\frac{\stackrel{\Xi}{E}}{Z}$ & 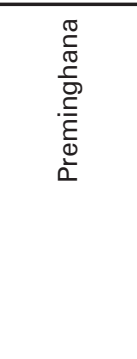 & 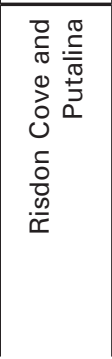 & 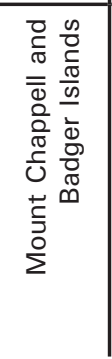 & $\begin{array}{l}0 \\
\sum_{3} \\
0 \\
0 \\
0 \\
0 \\
0 \\
\frac{1}{4}\end{array}$ & 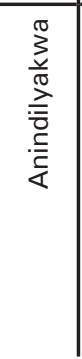 & 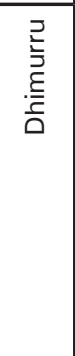 & 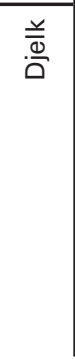 & 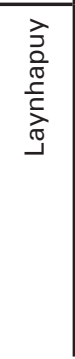 & 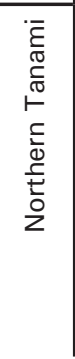 & $\begin{array}{l}\frac{c}{\Phi} \\
\frac{\overrightarrow{0}}{0} \\
\frac{0}{0} \\
\frac{0}{0} \\
3\end{array}$ \\
\hline
\end{tabular}


There are significant differences between PES and government funding for NRM, as well as other forms of economic participation. PES schemes involve individual buyers and sellers of environmental services. As such PES are not constrained within an overarching framework as in the case of government programs, and could be tailored according to the needs and aspirations of each Indigenous NRM group. In this regard, PES are similar to agreements between mining companies and Indigenous landowners, and would pose the same challenge of overcoming weaknesses in the bargaining position of Indigenous people (see O'Faircheallaigh 2008). Unlike mining agreements, PES-related activities do not cause damage to cultural heritage and Indigenous environments, so are less likely to invoke opposition from Indigenous communities. They also require active involvement of Indigenous knowledge and labour, thus creating both tangible (that is, economic) and symbolic outcomes that are central to Indigenous cultural identity (Scambary 2009).

\section{The Two Study Areas}

\section{The Dhimurru IPA}

Dhimurru (formerly known as Dhimurru Land Management Aboriginal Corporation) was established in 1992. Yolngu (Indigenous people from east Arnhem Land) were concerned about the impact of an increasing non-Indigenous population that followed the establishment of a bauxite mine and processing plant on their traditional lands. TOs run and control the organisation through the Dhimurru Board (Wa:nga-Watangu Yolngu) that includes representatives of 17 clans with interests in the region. The board sets management and access to recreational-area requirements (Dhimurru 2008). Dhimurru currently employs 16 Indigenous and six non-Indigenous staff. In the financial year 2008-09, Dhimurru had a budget of about $\$ 1.7$ million.

In 2000, Yolngu declared the Dhimurru IPA, covering about 92000 ha of land and 9000 ha of adjacent marine areas in the Gove Peninsula (Map 16.1). The IPA contains areas of important cultural and environmental value, hosting a significant representation of Australia's Arnhem Coast sub-bioregion ARC3 (DEWHA 2010a). Environmental values include high plant diversity, intact faunal assemblages, and significant feeding and nesting sites for threatened species of marine turtles and seabirds (Dhimurru 2008). Dhimurru IPA surrounds land leased to Rio Tinto Alcan (RTA) for bauxite mining and processing, and the townships of Nhulunbuy, Yirrkala and Gunyangara. 


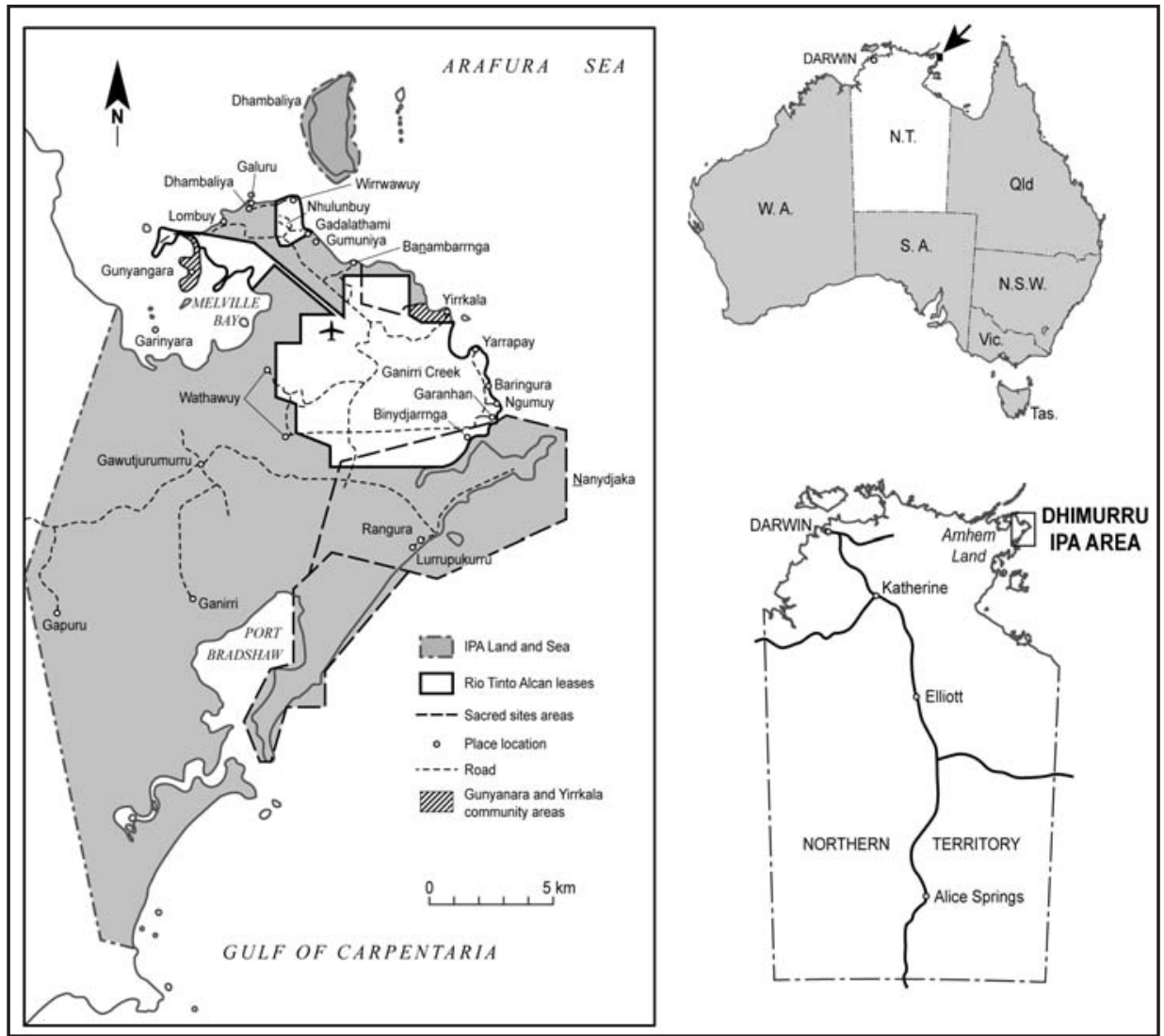

Map 16.1 The Dhimurru IPA

Source: Dhimurru (2008); map redrawn by Peter Johnson.

The primary focus of Dhimurru's activities is the protection of Yolngu values and conservation and enhancement of the natural and cultural values of the IPA. Dhimurru also fosters 'both-ways' management by integrating Yolngu and non-Indigenous sciences. The IPA is also managed according to International Union for Conservation of Nature (IUCN) Category V Guidelines for Protected Areas (Dudley 2008). Dhimurru's activities have interconnected goals: people management, environmental monitoring, conservation and restoration, heritage and cultural activities. People management includes permit checks, signs and sign maintenance, fencing, rubbish pick-ups, and campsite and track maintenance. These activities allow Dhimurru to limit and monitor use, compliance and access. Limits on use and access prevent conflict with local Indigenous communities. They also have important environmental and cultural outputs. Limiting access protects sites of cultural and environmental significance by avoiding damage caused by vehicle movements (weed and non-native ant spreading, fire scars, bush and tree damage, opening of new tracks, disturbance of fauna, damage 
to nesting sites, and so on) as well as by inappropriate behaviour (vandalism, extirpation of specimens, and so on). Alongside these preventive activities, Dhimurru Rangers carry out environmental management and conservation. This includes: crocodile trapping, tagging and relocating; weed monitoring, treatment and eradication; discarded ('ghost') fishing net recovery and turtle rescue; Australian Quarantine and Inspection Service (AQIS) contracted work (mosquito, ant and weed sampling and monitoring); marine debris and beach clean-ups.

\section{The Djelk IPA}

Djelk IPA was declared in 2009. It extends over 673200 ha, stretching from the Central Arnhem Plateau to the Arafura Sea (Map 16.2) in the Arnhem Coast sub-bioregion ARC-2 (DEWHA 2010b). Even though the IPA has been declared only recently, Djelk Rangers were established under the auspices of Bawinanga Aboriginal Corporation (BAC) in 1991. Djelk IPA comprises a biodiversityrich landscape, which is home to iconic species such as saltwater crocodiles, and the richest variety in the world of reptiles (DEWHA 2010b). It is also a landscape populated with the cultures of 107 clans representing more than 12 language groups. Senior TOs guide and control Djelk IPA management through the IPA Advisory Committee consisting of representatives of landowning clans. The committee also includes the BAC executive and a representative of the Federal Department of Environment, Water, Heritage and the Arts (DEWHA). Djelk currently employs 35 rangers, a Ranger Coordinator and a Special Project Officer. Rangers are divided into three groups (Sea, Land, and Women Rangers), each coordinated by a senior supervisor. Djelk's budget for the financial year 2008-09 amounted to about \$1.7 million.

The major responsibilities of Land and Women Rangers include burning, feral animal control and weed treatment to maintain biodiversity and productivity of the land through the use and transfer of both Indigenous and Western knowledge. Sea Rangers undertake management and surveillance up to 3 nautical miles off the coast. They focus on the protection of cultural and natural resources. Under fee-for-service agreements with Australian Customs and the NT Department of Resources-Fisheries, Djelk Sea Rangers patrol 200 km of coast to detect illegal, foreign and Australian fishing vessels and illegal migration, and to monitor recreational fishing.

There are substantial differences between Dhimurru and Djelk IPAs. Dhimurru's main activities focus on people management. The proximity of a mining town and mine operation to the Dhimurru IPA and the large non-Indigenous population pose the greatest threats to the conservation of cultural and natural assets. It also means that Dhimurru has a direct relationship with the mining 
company, which is a buyer of environmental services, as discussed in section four. Djelk Rangers have also several partners who buy their environmental services. Aside from selling services to Australian Customs, Fisheries and AQIS, Djelk Rangers are also part of the West Arnhem Land Fire Abatement (WALFA) scheme through which they sell carbon credits to a international company (see the next section).

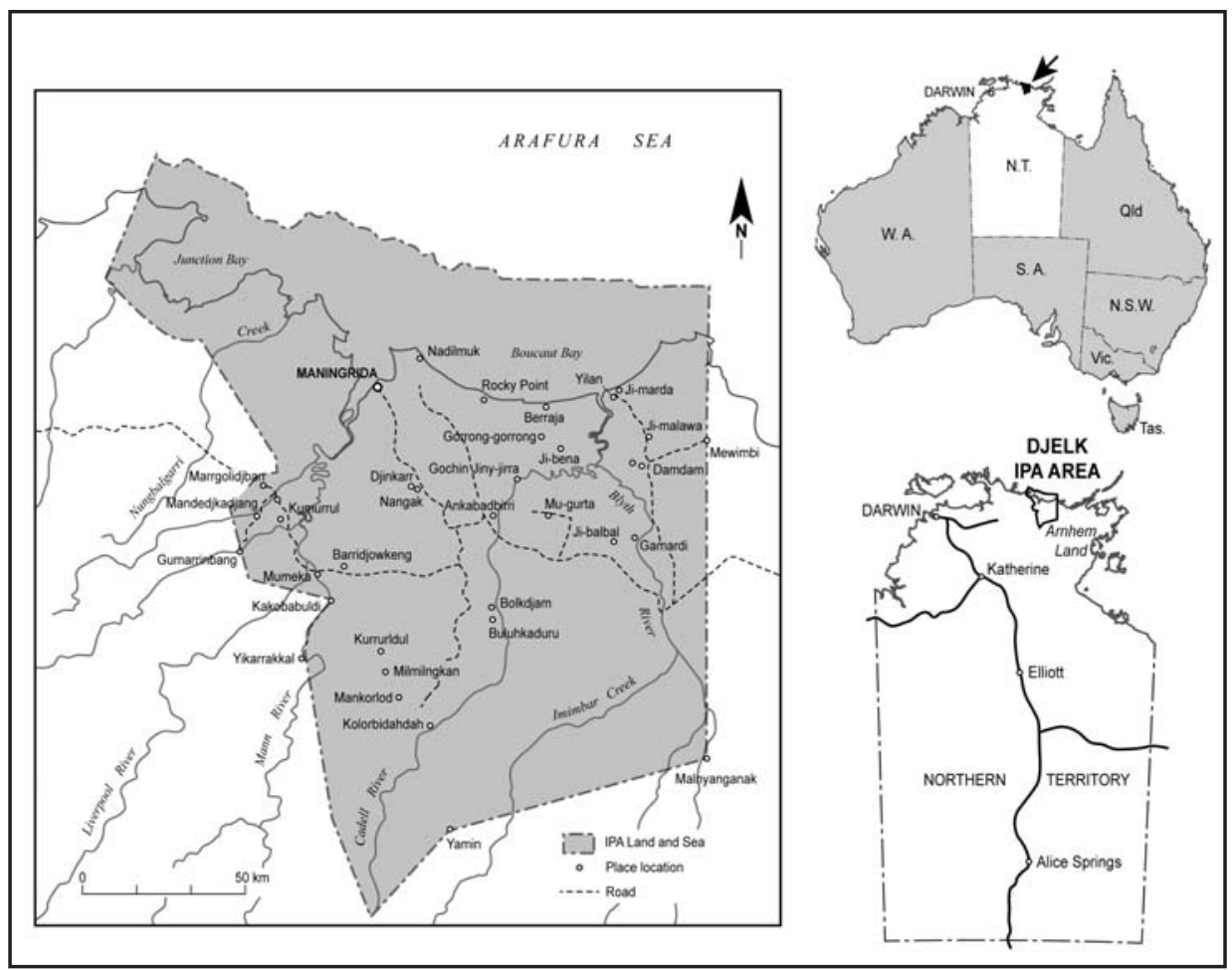

Map 16.2 The Djelk IPA

Source: Bawinanga (2009); map redrawn by Peter Johnson.

\section{Indigenous NRM and PES}

There are several contract-based arrangements currently operating in Indigenous Australia that have some or all of the characteristics of PES schemes. ${ }^{3}$

\footnotetext{
3 This does not include several additional PES or market-based schemes for environmental conservation that, in general, do not target Indigenous landowners or aim to address poverty issues (see, for instance, Yee and Clouston 2006).
} 


\section{The WALFA Scheme}

The Western Arnhem Land Fire Abatement (WALFA) project is an outcome-based PES scheme involving Indigenous landowners in the Djelk and Warrdekken IPAs and Darwin Liquefied Natural Gas (DLNG) through a contractual agreement brokered by the NT Government and the Northern Land Council. It is the first large-scale commercial provision of environmental services in Indigenous Australia. According to this agreement, signed in 2005, Indigenous Rangers and TOs implement strategic fire management aimed at reducing the number of highly destructive, high in greenhouse gas (GHG) emission, late-season fires through prescribed early season burning across 28 million ha of western Arnhem Land. The reduction in GHG emissions and enhanced environmental protection offset the environmental impact of the liquefied natural gas plant in Darwin. In return, DLNG pays the TOs \$1 million per year (in 2006 dollars) for 17 years. The target reduction of 100000 tonnes of carbon dioxide equivalent per year relative to a 10-year baseline (1995-2004) has been regularly met (BAC 2007). The WALFA agreement is entirely voluntary, and carbon credits generated by the project are not tradable. The project's goals include environmental protection in the Arnhem Land Plateau, transfer of traditional ecological knowledge, assistance to TOs' return to country, as well as provision of economic benefits to the communities involved (Whitehead et al. 2009). While successfully delivering the expected outcomes, the project has also highlighted important issues relating to benefit sharing, potential conflicts between commercial versus customary use of natural resources, and lack of a national framework for carbon trading and emission abatement from fire management (Whitehead et al. 2009).

\section{AQIS Fee-for-Service Program}

Australian Quarantine Inspection Services (AQIS) and the NT Department of Primary Industries, Fisheries and Mines run an outcome-based or 'fee-forservices' program through which AQIS contracts Indigenous landowners and rangers to provide weed, insect and marine debris monitoring services (Muller 2008). AQIS pays for vehicle and vessel time, and provides full pay for up to two rangers to collect weed and insect samples, and patrol the coasts. There are few data about the outputs and outcomes of this program. Dhimurru earned about $\$ 8000$ in 2008 from the AQIS contract (Dhimurru, Personal communication). As Dhimurru runs a \$2 million operation, the AQIS fee-for-service scheme clearly has little financial impact. During informal talks with AQIS officers, it emerged that Indigenous male rangers are not always willing to take up weed and insect monitoring, but are usually eager to run marine debris patrols. One can speculate that the reason for this is that weeds and insect monitoring are not activities traditionally performed by Indigenous landowners. AQIS contracts run from 
year to year, and they offer no support for start-up costs, such as purchase of vehicles and vessels, so Indigenous rangers need to first access resources for these substantial initial investments.

\section{Customs' Indigenous Rangers Program}

A third PES-type scheme is the Indigenous Rangers Program run by Australian Customs and Border Protection Service. Under this program, Customs engages Indigenous rangers in maritime surveillance and biosecurity services. The program started as a pilot project in 2005 with a fee-for-services agreement between the Djelk Rangers and Customs. Under the agreement, Djelk Rangers initially received about $\$ 250000$ to employ two rangers in sea patrols. Djelk Rangers have intercepted several illegal fishing vessels and provided evidence for successful prosecution. In 2007 the scheme was extended to involve the Bardi Jawi Rangers in Western Australia and Aurukun Rangers in Queensland through a $\$ 623000$ commitment by the Federal Government (ACS 2007; FaHCSIA 2007).

\section{Dhimurru and RTA Fee-for-Service Agreements}

Since 2005 Rio Tinto Alcan (RTA) has contracted Dhimurru to carry out some ethno-ecology monitoring in Melville Bay, adjacent to the RTA bauxite refinery and shipping facilities, and bordering Dhimurru IPA. The contract requires Dhimurru to develop and provide ongoing maintenance of an ethno-ecological database, as well as supporting sampling activities in the bay by providing a vessel and crew. RTA committed to regular payments of about $\$ 40000$ per year. The contract expired last year, and has not been renewed, partly because of the global financial crisis, but also because Dhimurru has not delivered according to contractual requirements (Dhimurru, Personal communication).

Similarly, in 2008, RTA and Dhimurru initiated talks to contract archaeological surveying of the RTA mining area. Dhimurru proposed to take responsibility of TOs' inputs in cultural resource identification, recruit professional expertise and undertake field survey work. The project also had important training elements for Dhimurru. After Dhimurru undertook two trial surveys, however, RTA halted the project following the global financial crisis (Dhimurru, Personal communication).

While all these schemes meet the conditions for PES outlined above (voluntary in nature, payment on delivery, specified services, identified buyer and seller), there are some important differences among them that partially explain their different outcomes, as discussed in the next section. 


\section{Discussion}

The success of the IPA program in Australia is based on several factors. Government funding has supported TOs focused on managing their traditional estates and protecting heritage. Strong Indigenous knowledge and governance have guided environmental conservation. Both Dhimurru and Djelk IPAs are outstanding examples of how to balance the needs of Indigenous landowners with the requirements attached to government funding. This balance is producing important environmental outcomes, as well as employment opportunities for Indigenous people living in remote Australia. Overall, the increasing number of IPAs and the renewed commitment of the Federal Government indicate that IPAs are seen as an instrument through which Indigenous groups can empower themselves and transform their marginalised status in Australia's economic and political space.

A critical area needing to be addressed is the coordination of the IPA program with other government programs and overarching policy frameworks. In particular, the Closing the Gap framework (COAG 2009) is in direct conflict with the efforts of Indigenous landowners to stay on and care for their country. Also, the voluntary nature of the IPA agreements means that governments are not required to provide any specific commitment, particularly in terms of revising existing policies with negative impacts on the environment. For instance, declaring an IPA does not preclude or extinguish mining rights: 30 per cent of the newly declared Djelk IPA is under mining exploration leases (Djelk Rangers, Personal communication). Indigenous rangers also have no control over activities that impact on the IPA but occur outside its boundaries. In the Gove Peninsula, for instance, bauxite mining and refining have a large ecological footprint, with likely negative effects on the surrounding Dhimurru IPA. Further, Indigenous rangers demand better recognition of the links between cultural and environmental management both at funding and at reporting levels (Dhimurru, Personal communication).

The review of the existing PES schemes involving Djelk and Dhimurru Rangers highlights weaknesses, constraints and opportunities. Some weaknesses relate to the TOs' ability (or lack of) to negotiate contractual agreements with buyers of environmental services. WALFA, for instance, is the result of a long process of government-funded research, information and negotiation that included every aspect of the arrangement. In comparison, the AQIS fee-for-service scheme is a take-it-or-leave-it arrangement. Indigenous landowners have no chance of negotiating compensation, length and methods of undertaking the activities, and hence no possibility of developing a contractual arrangement that best matches their cultural, social and environmental needs and responsibilities. Negotiations would guarantee a degree of autonomy in the implementation of contracted 
activities, so that they can fit around Indigenous cultural and environmental responsibilities. This might clash with canonical notions of contracted labour, where work requires a hierarchical structure of command, unlike Yolngu circular governance structures (see, for instance, Marika et al. 2009).

Negotiations should also ensure that activities required for the generation of the contracted environmental services match traditional management practices. Whenever this match does not occur, and when conflicting cultural priorities are apparent (see the case of water buffaloes described in Albrecht et al. 2009), negotiations should focus on making Indigenous and non-Indigenous interests converge prior to setting up any PES scheme. There seems to be a better match between Indigenous NRM activities, cultural priorities and contracted activity in the case of WALFA than with AQIS contracts and the RTA ethnoecological survey. AQIS monitoring activities require skills and knowledge that, possibly, are not closely related to existing Indigenous knowledge and management practices. In the case of RTA ethno-ecological surveys, Dhimurru's IPA management demanded most of its resources, and Dhimurru could only partially fulfil the contract requirements.

Financial constraints and lack of skills are major limiting factors for PES schemes. Lack of skills for the execution of the contractual commitments requires PES schemes to provide the necessary training. For example, complex PES schemes such as the Customs Indigenous Rangers Program require training in several areas: coxswain, maritime safety, law compliance and enforcement. Potential environmental service buyers might find that investing in training is not feasible, or not even proper, as in the case of federal agencies relinquishing enforcement powers in favour of Indigenous landowners.

Further, Indigenous knowledge and management practices might not be suited to addressing new or emerging environmental trends and threats, such as weeds and feral animals, protection of threatened species and climate change (Garnett and Woinarski 2007), and hence limit the type of environmental services they can provide. As Luckert et al. (2007) state, there is a strong case for governments to invest in improving Indigenous landowners' skills in NRM, and to properly fund and support basic ecological and environmental research on Indigenousowned land. Only such commitment would secure the long-term success of the IPA program on environmental and social grounds, and open new avenues for PES-type arrangements.

It also appears that financial elements limit the ability of Indigenous communities to participate in PES. One of these constraints is the need for upfront investments in vehicles, vessels or other assets. As the AQIS scheme does not provide sufficient resource for these start-up costs, it is plausible to say that some Indigenous groups willing to enter the scheme are not able for lack 
of basic capital. Indeed, in the case of WALFA, the project has been successful also because the Indigenous communities involved have a well-resourced ranger group and Outstation Resource Agency (ORA) that have been able to provide the necessary capital. It should also be noted that PES schemes could expose Indigenous landowners to the instability of international markets, especially in the mineral sector, as is the case of Dhimurru contractual relationships with RTA. These risks could deter some Indigenous landowners and organisations from making the initial investments necessary to provide environmental services.

Best-practice PES schemes are based on ongoing payments, both to ensure environmental service delivery and to signal serious commitment from buyers (World Bank 2009). It is common for the Federal Government to set up pilot schemes that go on for several years - such as the Customs Indigenous Ranger Program - without developing them into full-scale financial commitments that maximise environmental benefits and promote local development. Indeed, securing long-term funding has always been one of the major problems for Indigenous NRM groups. The success of the WALFA project seems to indicate the need for long-term agreements.

It should also be noted that, as Indigenous Australians might have different sets of incentives and cultural demands, one should not expect that PES are automatically taken up by traditional owners. Monetary incentives might not be enough to ensure the delivery of contracted service, undertake conservation work or change management practices. Weed and insect monitoring through AQIS fee-for-service, for instance, have not been particularly successful with Dhimurru Rangers.

Practitioners have also identified other problems with PES. Market exchange through PES can be realised only for environmental and cultural elements that can be commodified. This can limit the scope for PES applicability, as well as risk the conflation of a set of systemic cultural and environmental complexities in commercialised elements, with potentially detrimental effects on the system (Norgaard 2010). Indigenous rangers are indeed demanding that governments recognise the links between environmental and cultural practices, and the holistic approach driving their land management practices.

PES linked to offsetting schemes - while potentially positive for the local environment and culture-have zero effect on the global environment. For example, global GHG emissions are not decreasing as a result of the WALFA project, as required in order to reduce the probability of serious adverse effects as a result of climate change (IPCC 2007). Finally, the impact of PES in reducing poverty and addressing environmental issues cannot be assessed without considering the overall effects in the local economy and policy settings. There 
is evidence, for example, that some PES schemes create little gains for nonparticipants, and that some participants might not gain at all when the scheme is poorly linked to the rest of the economy (Bulte et al. 2008).

Opportunities exist to further engage Indigenous landowners as providers of environmental services. The NT Environmental Protection Agency (EPA), for instance, should consider collaborative arrangements with Indigenous rangers for monitoring the impacts of industrial and economic development. Recent industrial accidents in RTA mining facilities near Dhimurru IPA have highlighted the importance of constant environmental monitoring and public availability of the results. Establishing effective maritime surveillance and enforcement systems is also seen as an important way to engage Indigenous rangers and Indigenous knowledge, and to ensure respectful recognition of Indigenous rights to the sea (Dhimurru 2006).

While new opportunities are now developing for Indigenous NRM to sustain an integrated customary-market-state economy, it should be noted that Yolngu people, for example, have always made clear their aspirations. In the words of senior Yolngu landowners, they 'wish to contribute to regional and national economic development, in keeping with...time-honoured responsibilities to care for land and sea' (Dhimurru 2006).

\section{References}

Albrecht, G., McMahon, C., Bowman, D. and Bradshaw, C. 2009. Convergence of culture, ecology, and ethics: management of feral swamp buffalo in northern Australia. Journal of Agricultural and Environmental Ethics 22 (4): 361-78.

Altman, J. C. and Martin, D. (eds) 2009. Power, culture, economy: Indigenous Australians and mining. CAEPR Research Monograph No. 30, Centre for Aboriginal Economic Policy Research, Australian National University, Canberra, <http://online.anu.edu.au/caepr/mono.php >

Altman, J. C. and Whitehead, P. J. 2003. Caring for country and sustainable Indigenous development: opportunities, constraints and innovation. CAEPR Working Paper No. 20, Centre for Aboriginal Economic Policy Research, Australian National University, Canberra, <http://online.anu.edu.au/caepr/ working.php>

Altman, J. C., Buchanan, G. J. and Larsen, L. 2007. The environmental significance of the Indigenous estate: natural resource management as economic development 
Indigenous Participation in Australian Economies II

in remote Australia. CAEPR Discussion Paper No. 286, Centre for Aboriginal Economic Policy Research, Australian National University, Canberra, <http:// online.anu.edu.au/caepr/discussion.php>

Austin-Broos, D. 2003. Places, practices, and things: the articulation of Arrernte kinship with welfare and work. American Ethnologist 30 (1): 118-35.

Australian Bureau of Statistics (ABS) 2007. Australian Standard Geographical Classification. Canberra: Australian Bureau of Statistics. Viewed 26 May 2010, <http://www.abs.gov.au/AUSSTATS/abs@.nsf/DetailsPage/1216.0Jul\%20 2007?OpenDocument>

Australian Bureau of Statistics (ABS) 2010. Australian Social Trends. Canberra: Australian Bureau of Statistics. Viewed 26 May 2010, <http://www.abs.gov. au/ausstats/abs@.nsf/mf/4102.0>

Australian Customs Service (ACS) 2007. Indigenous Ranger Program. Canberra: Australian Customs Service. Viewed 4 October 2009, <http://www.customs. gov.au/webdata/minisites/annualReport0607/pages/page36.html>

Australian Employment Covenant (AEC) 2010. Fifty Thousand Sustainable Indigenous Jobs. Viewed 6 June 2010, <http://www.fiftythousandjobs.com.au/>

Bawinanga Aboriginal Corporation (BAC) 2007. Annual Report. Maningrida, NT: Bawinanga Aboriginal Corporation.

Bawinanga Aboriginal Corporation (BAC) 2009. Djelk Indigenous Protected Area Management Plan. Maningrida, NT: Bawinanga Aboriginal Corporation.

Biddle, N. 2009. The geography and demography of Indigenous migration: insights for policy and planning. CAEPR Working Paper No. 58, Centre for Aboriginal Economic Policy Research, Australian National University, Canberra, <http:// online.anu.edu.au/caepr/working.php>

Bulte, E. H., Lipper, L., Stringer, R. and Zilberman, D. 2008. Payments for ecosystem services and poverty reduction: concepts, issues, and empirical perspectives. Environment and Development Economics 13 (3): 245-54.

Commonwealth of Australia 2010. What is Caring for Our Country? Canberra: Commonwealth of Australia. Viewed 3 February 2010, <http://www.nrm. gov.au/about/caring/index.html>

Council of Australian Governments (COAG) 2009. National Indigenous Reform Agreement (Closing the Gap). Canberra: Council of Australian Governments. Viewed 10 March 2010, <http://www.coag.gov.au/intergov_agreements/ federal_financial_relations/docs/IGA_FFR_ScheduleF_National_ Indigenous_Reform_Agreement.pdf $>$ 
Department of the Environment, Water, Heritage and the Arts (DEWHA) 2010a. Dhimurru Indigenous Protected Area. Canberra: Commonwealth of Australia. Viewed 3 March 2010, <http:/www.environment.gov.au/indigenous/ipa/ declared/dhimurru.html>

Department of the Environment, Water, Heritage and the Arts (DEWHA) 2010b. Djelk Indigenous Protected Area. Canberra: Commonwealth of Australia. Viewed 3 March 2010, <http://www.environment.gov.au/indigenous/ipa/ declared/djelk.html>

Department of the Environment, Water, Heritage and the Arts (DEWHA) 2010c. Indigenous Protected Areas. Canberra: Commonwealth of Australia. Viewed 10 May 2010, <http://www.environment.gov.au/indigenous/ipa/index.html>

Department of the Environment, Water, Heritage and the Arts (DEWHA) 2010d. Sea Country Indigenous Protected Areas. Canberra: Commonwealth of Australia. Viewed 3 March 2010, <http://www.environment.gov.au/ indigenous/ipa/sea.html>

Department of Families, Housing, Community Services and Indigenous Affairs (FaHCSIA) 2007. Illegal Foreign Fishing-Indigenous rangers trial. Canberra: Commonwealth of Australia. Viewed 4 October 2009, <http://www.fahcsia. gov.au/about/publicationsarticles/corp/BudgetPAES/budget2007-08/ budget2007-07_indigenous/Pages/budget2007-07_indigenous_19.aspx>

Dhimurru 2006. Sea Country Plan. Nhulunbuy, NT: Dhimurru Aboriginal Corporation.

Dhimurru 2008. IPA Plan of Management 2008 to 2015. Nhulunbuy, NT: Dhimurru Aboriginal Corporation.

Dudley, N. 2008. Guidelines for Applying Protected Area Management Categories. Gland, Switzerland: International Union for Conservation of Nature.

Engel, S., Pagiola, S. and Wunder, S. 2008. Designing payments for environmental services in theory and practice: an overview of the issues. Ecological Economics 65 (4): 663-74.

Garnett, S. T. and Woinarski, J. 2007. A case for Indigenous threatened species management. In M. K. Luckert, B. M. Campbell, J. T. Gorman and S. T. Garnett (eds), Investing in Indigenous Natural Resource Management. Darwin: Charles Darwin University Press. 
Indigenous Participation in Australian Economies II

Gilligan, B. 2006. The National Reserve System Programme 2006 Evaluation. Canberra: Department of the Environment and Heritage. Viewed 10 March 2010, <http://www.environment.gov.au/parks/publications/nrs/ evaluation-2006.html>

Greiner, R., Gordon, I. and Cocklin, C. 2009. Ecosystem services from tropical savannas: economic opportunities through payments for environmental services. The Rangeland Journal 31 (1): 51-9.

Heath, J. and Binswanger, H. 1996. Natural resource degradation effects of poverty and population growth are largely policy-induced: the case of Colombia. Environment and Development Economics 1 (1): 65-84.

Hill, R., Harding, E. K., Edwards, D., O'Dempsey, J., Hill, D., Martin, A. and McIntyre-Tamwoy, S. 2007. A cultural and conservation economy for northern Australia. Final report to Land and Water Australia. Canberra: Land and Water Australia. Viewed 5 October 2009, <http://wa.gov.au/products/ pr071437>

Hudson, S. 2009. Out with the old: are the CDEP reforms enough? Policy (Summer 2008-09).

Kingwell, R., John M. and Robertson, M. 2008. A review of a community-based approach to combating land degradation: dryland salinity management in Australia. Environment, Development and Sustainability 10 (6): 899-912.

Intergovernmental Panel on Climate Change (IPCC) 2007. Climate Change 2007: Synthesis report. Valencia, Spain: Intergovernmental Panel on Climate Change.

Langton, M., Rhea, Z. M. and Palmer, L. 2005. Community-oriented protected areas for Indigenous people and local communities, Journal of Political Ecology 12: 23-50.

Lindsay, N. J. 2005. Toward a cultural model of Indigenous entrepreneurial attitude. Academy of Marketing Science Review 5: 1-15.

Luckert, M. K., Campbell, B. M., Gorman, J. T. and Garnett, S. T. (eds) 2007. Investing in Indigenous Natural Resource Management. Darwin: Charles Darwin University Press.

Maningrida Arts \& Culture (MAC) 2008. Annual Report 2007-08. Maningrida, NT: Maningrida Arts \& Culture.

Marika, R., Yunupingu Y., Marika-Mununggiritj, R. and Muller, S. 2009. Leaching the poison - the importance of process and partnership in working with Yolngu. Journal of Rural Studies 25 (4): 404-13. 
Marsh, S. P. and Pannell, D. 2000. Agricultural extension policy in Australia: the good, the bad and the misguided. The Australian Journal of Agricultural and Resource Economics 44 (4): 605-27.

Muller, S. 2008. Indigenous payment for environmental service (PES). Opportunities in the Northern Territory: negotiating with customs. Australian Geographer 39 (2): 149-70.

Norgaard, R. B. 2010. Ecosystem services: from eye-opening metaphor to complexity blinder. Ecological Economics 69 (6): 1219-27.

Northern Land Council (NLC) 2006. Celebrating Ten Years of Caring for Country. A Northern Land Council initiative. Darwin: Northern Land Council.

O'Faircheallaigh, C. 2008. Negotiating cultural heritage? Aboriginal-mining company agreements in Australia. Development and Change 39 (1): 25-51.

Pagiola, S., Rios, A. R. and Arcenas, A. 2008. Can the poor participate in payments for environmental services? Lessons from the silvipastoral project in Nicaragua. Environment and Development Economics 13 (3): 299-325.

Parsons, W. and Cuthbertson E. 1992. Noxious Weeds of Australia. Melbourne and Sydney: Inkata Press.

Russel-Smith, J., Whitehead, P. and Cooke, P. 2009. Culture, Ecology and Economy of Fire Management in North Australian Savannas: Rekindling the Wurrk tradition. Collingwood, Vic.: CSIRO Publishing.

Scambary, B. 2009. Mining agreements, development, aspirations, and livelihoods. In J. Altman and D. Martin (eds), Power, Culture, Economy: Indigenous Australians and mining. CAEPR Research Monograph No. 30, Centre for Aboriginal Economic Policy Research, Australian National University, Canberra.

Smith, N. 1995. Weeds of Natural Ecosystems: A field guide to environmental weeds of the Northern Territory. Darwin: Environment Centre Northern Territory.

Smyth, D., Szabo, S. and George, M. 2004. Case studies in Indigenous engagement in natural resource management in Australia. Prepared for the Department of Environment and Heritage, Commonwealth of Australia, Canberra. <http:// www.nrm.gov.au/publications/case-studies/pubs/indigenous-engagement. $\mathrm{pdf}>$ 
Indigenous Participation in Australian Economies II

Whitehead, P. J. 2007. A general case for natural resource management: market failure and government policy. In M. K. Luckert, B. M. Campbell, J. T. Gorman and S. T. Garnett (eds), Investing in Indigenous Natural Resource Management. Darwin: Charles Darwin University Press.

Whitehead, P. J., Purdon, P., Cooke, P. M., Russel-Smith, J. and Sutton, S. 2009. The West Arnhem Land Fire Abatement (WALFA) project: the institutional environment and its implications. In J. Russel-Smith, P. J. Whitehead and P. Cooke (eds), Culture, Ecology and Economy of Fire Management in North Australian Savannas: Rekindling the Wurrk tradition. Collingwood, Vic.: CSIRO Publishing.

Williams, N. M. 1986. The Yolngu and their Land. Stanford, Calif.: Stanford University Press.

Woinarski, J., Mackey, B., Nix, H. and Traill, B. 2007. The Nature of Northern Australia. Canberra: ANU E Press.

World Bank 2009. Best Practice in PES Design. Washington, DC: The World Bank. Viewed 5 October 2009, <http://go.worldbank.org/B8H9WA8W30>

Wunder, S. 2005. Payments for Environmental Services: some nuts and bolts. Occasional Paper No. 42, Center for International Forestry Research, Bogor, Indonesia.

Yee, S. and Clouston, B. 2006. Round 1 Market Based Instruments Pilot ProgramsOverview and implications for regional NRM groups in Queensland. Brisbane: Department of Natural Resources, Mines and Water.

\section{Acknowledgments}

The author gratefully acknowledges the Tropical Rivers and Coastal Knowledge (TRaCK) research hub and the Australian Rivers Institute for funding this study. TRaCK receives major funding for its research through the Australian Government's Commonwealth Environment Research Facilities initiative, the Australian Government's Raising National Water Standards Program, Land and Water Australia, the Fisheries Research and Development Corporation and the Queensland Government's Smart State Innovation Fund. 